\title{
Application of appropriate technology for making hand sanitizer with Citronella Oil
}

\section{Penerapan teknologi tepat guna pembuatan hand sanitizer dengan Minyak Sereh Wangi}

\author{
Dante Alighiri', Sigit Priatmoko', Samuel Budi Wardhana Kusuma1', Sri Nurini², \\ Eko Budi Susatyo ${ }^{1}$ \\ ${ }^{1}$ Departemen Kimia, Fakultas Matematika dan Ilmu Pengetahuan Alam, Universitas Negeri Semarang \\ Kampus Sekaran Gunungpati, Semarang, 50229, Indonesia \\ 2SD Negeri Genuksari 02 Semarang, Jl. Dong Biru, Genuksari, Genuk, Semarang, 50117, Indonesia
}

\begin{abstract}
ARTICLE INFO:
Received: 2021-04-20

Revised: 2021-08-11

Accepted: 2021-12-04

Keywords:

Citronella oil, Community service, Hand sanitizer,

Orphanage

ABSTRACT

The vision of the orphanage is to create a society that is physically and mentally prosperous through empowering underprivileged children, progressively and professionally to form a generation of Khaira Ummah. To support this, the community service team needs to equip the orphanage children with knowledge and skills that are expected to provide creative ideas in entrepreneurship through the application of appropriate technology for the production of hand sanitizer from citronella oil. The resulting hand sanitizer has two functions as a natural hand antiseptic and mosquito repellent. The stages of this community service activity had been carried out by the methods of lectures, discussions, demonstrations, and practices. After the activities were completed, assistance and evaluation of activities were carried out. Almost all participants had been a level of understanding of all community service activities (> 90\%) which included knowledge, skills, perception, and motivation. The evaluation of the activities had been carried out by 95 s of participants, satisfied with this community service activity. This community Service activity had been succeeded in equipping the orphanage children and supporting the vision of the orphanage of Khaira Ummah.
\end{abstract}

(c) 2022 Abdimas: Jurnal Pengabdian Masyarakat Universitas Merdeka Malang This is an open access article distributed under the CC BY-SA 4.0 license (https://creativecommons.org/licenses/by-sa/4.0/)

How to cite: Alighiri, D., Priatmoko, S., Kusuma, S. B. W., Nurini, S., \& Susatyo, E. B. (2021). Application of appropriate technology for making hand sanitizer with Citronella Oil. Abdimas: Jurnal Pengabdian Masyarakat Universitas Merdeka Malang, 7(1), 94-102. https://doi.org/10.26905/abdimas.v7i1.5715

\section{PENDAHULUAN}

Panti asuhan merupakan salah satu lembaga sosial perlindungan anak yang berfungsi sebagai perlindungan terhadap anak-anak sehingga anak dapat hidup dengan normal sesuai dengan usainya (Setiawan \& Pasau, 2017). Panti asuhan berfungsi sebagai pengganti peranan orang tua dalam memberikan kebutuhan mental dan sosial pada anak asuh agar mereka memiliki kesempatan yang luas untuk mengalami pertumbuhan fisik dan mengembangkan pemikiran hingga mencapai tingkat kedewasaan yang matang dan mampu melaksanakan peranannya sebagai individu dan warga negara di dalam 
kehidupan bermasyarakat. Panti asuhan juga sebagai tempat dalam mengembangkan potensi anak. Sehingga semua bakat yang ada pada diri anak dapat disalurkan dengan baik dan terhindar dari segala tindakan yang negatif (Aziz et al., 2020). Salah satu panti asuhan yang menjalankan fungsi tersebut adalah Panti Asuhan Yatim Piatu dan Dhuafa Khaira Ummah. Panti asuhan ini terletak di Desa Sriwulan, Kecamatan Sayung, Kabupaten Demak.

Panti Asuhan Yatim Piatu dan Dhuafa Khaira Ummah, Sriwulan, Sayung, Demak merupakan panti asuhan yang berdiri sejak tahun 2002, dan secara hukum terdaftar dalam akta notaris Mustari Sawilin, S.H., pada tanggal 20 Mei 2003. Panti asuhan ini didirikan untuk meningkatkan kesejahteraan sosial anak di sekitar Kabupaten Demak terutama melalui pendidikan. Visi dari Panti Asuhan Yatim Piatu dan Dhuafa Khaira Ummah yaitu mewujudkan masyarakat yang sejahtera lahir batin melalui pemberdayaan anak-anak yang tidak beruntung, secara progresif dan profesional untuk membentuk generasi khaira ummah. Dengan demikian, panti asuhan merupakan tempat pendidikan anak terutama pendidikan non formal yang berperan serta dalam meningkatkan dan mengembangkan sikap serta kepribadian anak agar menjadi pribadi yang baik dan mandiri. Berdasarkan hal tersebut dan dalam rangka mendukung visi Panti Asuhan Yatim Piatu dan Dhuafa Khaira Ummah, maka Tim Pengabdi bersama dengan Pengurus Panti Asuhan perlu membekali anak-anak panti asuhan dengan keterampilan yang diharapkan dapat memberikan ide kreatif dalam berwirausaha melalui penerapan teknologi tepat guna produksi hand sanitizer minyak sereh wangi di Panti Asuhan Khaira Ummah Sriwulan, Sayung, Demak.

Hand sanitizer merupakan sediaan cair pembersih tangan yang memiliki kemampuan antibakteri dalam menghambat hingga membunuh bakteri dan penggunaannya tanpa menggunakan air yang mengandung bahan aktif antibakteri seperti turunan senyawa klor atau hidrogen peroksida sekitar 0,1-1\% dan alkohol 60-80\%. Namun demikian, senyawa aktif antibakteri tersebut bersifat karsinogenik (Alfhili \& Lee, 2019). Oleh karena itu, diperlukan alternatif untuk membuat hand sanitizer yang aman. Salah satu bahan alam yang dapat menggantikan bahan aktif yang berfungsi sebagai antiseptik adalah sereh wangi yang banyak tumbuh di kawasan sekitar Panti Asuhan Khaira Ummah.

Sereh wangi adalah salah satu tanaman penghasil minyak atsiri. Minyak atsiri yang terkandung dalam sereh wangi memiliki khasiat salah satunya sebagai antibakteri dan antiseptik. Oleh karena itu, komponen minyak sereh wangi adalah citronellal, citronellol, dan geraniol yang manfaat paling terkenalnya sebagai mosquito repellent alami. Jadi produk hand sanitizer yang dihasilkan nanti akan mempunyai dua fungsi sekaligus (double action) yaitu selain sebagai antiseptik tangan juga berfungsi sebagai mosquito repellent alami (Choiriyah et al., 2021; Syafi'l et al., 2020; Eden et al., 2020; Alighiri et al., 2018; Eden et al., 2018; Alighiri et al., 2017; Sastrohamidjojo, 2004).

Melihat potensi manfaat yang besar dari sereh wangi ini yang banyak tumbuh disekitar Panti Asuhan Khaira Ummah terutama untuk diaplikasikan dalam pembuatan hand sanitizer yang khas dan dalam rangka mendukung visi Panti Asuhan Khaira Ummah khususnya dalam membekali anak-anak panti dalam menumbuhkan jiwa kewirausahaan yang khas sehingga dapat berkompetisi dengan produk hand sanitizer lainnya, maka perlu diberikan pengetahuan dan keterampilan melalui program Pemberdayaan dan Pengabdian Masyarakat (PPM), Fakultas Matematika Ilmu Pengetahuan Alam, Universitas Negeri Semarang.

Dengan memberikan pengetahuan dan keterampilan yaitu penerapan teknologi tepat guna produksi hand sanitizer berbasis minyak sereh wangi berpeluang untuk dijadikan potensi bisnis baru. Hasil produksi ini nantinya dapat dipasarkan melalui toko-toko keperluan sehari-hari, swalayan, rumah makan, maupun melalui koperasi di Panti Asuhan Yatim Piatu dan Dhuafa Khaira Ummah Sriwulan, Sayung, Demak. Adapun luaran yang diharapkan dari pengabdian ini yaitu dapat diproduksinya double action hand sanitizer berbasis minyak sereh wangi sebagai antiseptik dan mosquito repellent alami. 
ABDIMAS: Jurnal Pengabdian Masyarakat Universitas Merdeka Malang

Volume 7, No 1, February 2022: 94-102

\section{METODE}

Kegiatan PPM dilaksanakan di Panti Asuhan Yatim Piatu dan Dhuafa Khaira Ummah, Sriwulan, Sayung, Demak pada tanggal 8 dan 15 November 2020. Sasaran kegiatan ini adalah seluruh anak-anak Panti Asuhan Yatim Piatu dan Dhuafa Khaira Ummah yang berjumlah 38 orang. Metode pelaksanaan kegiatan meliputi beberapa tahap.

\section{Persiapan kegiatan PPM}

Adapun persiapan yang dilakukan untuk mewujudkan kegiatan PPM ini adalah: (1) Tim PPM melakukan koordinasi dengan mitra dan LP2M Universitas Negeri Semarang yang mencakup administrasi dan perizinan; (2) Proses sosialisasi tentang penerapan teknologi formulasi double action hand sanitizer berbasis minyak sereh wangi sebagai antiseptik dan mosquito repellent.

\section{Pelaksanaan kegiatan PPM}

Pelaksanaan kegiatan PPM meliputi: (1) Ceramah dan diskusi tentang pengetahuan double action hand sanitizer berbasis minyak sereh wangi sebagai antiseptik dan mosquito repellent. Materi disiapkan dalam bentuk handout dan leaflet; (2) Demonstrasi dan praktik produksi hand sanitizer berbasis minyak sereh wangi sebagai antiseptik dan mosquito repellent; (3) Pendampingan praktik kegiatan produksi formulasi double action hand sanitizer berbasis minyak sereh wangi sebagai antiseptik dan mosquito repellent berdasarkan pengetahuan yang diperoleh dalam kegiatan sosialisasi; (4) Melakukan analisis kualitas produk double action hand sanitizer berbasis minyak sereh wangi sebagai antiseptik dan mosquito repellent.

\section{Prosedur kerja teknologi formulasi double action hand sanitizer}

Pembuatan double action hand sanitizer berbasis minyak sereh wangi yang dilakukan dalam pengabdian ini sesuai dengan standar dari WHO (World Health Organizaton, 2020) yang dimodifikasi dengan penambahan minyak sereh wangi dan air filtrat atau hydrosol dari minyak sereh wangi yang bersifat sebagai antiseptik dan mosquito repellent alami. Minyak sereh wangi yang digunakan sesuai dengan Standar Nasional Indonesia (Standar Nasional Indonesia, 1995). Formula double action hand sanitizer berbasis minyak sereh wangi sebagai antiseptik dan mosquito repellent pada pengabdian ini ditunjukkan dalam Tabel 1.

Tabel 1. Formula double action hand sanitizer berbasis minyak sereh wangi

\begin{tabular}{|c|c|}
\hline Raw Material & Persentase (\%) \\
\hline Etanol 96\% & 20 \\
\hline Isopropil Alkohol (IPA) 99,8\% & 54 \\
\hline Minyak Sereh Wangi & 1 \\
\hline Air Hydrosol Sereh Wangi & 23 \\
\hline Glycerol 98\% & 2 \\
\hline
\end{tabular}

\section{Monitoring evaluasi kegiatan PPM}

Evaluasi terhadap keterampilan mitra dilakukan melalui unjuk kerja pada semua aspek produksi teknologi formulasi. Evaluasi praktik dilakukan setiap akhir pertemuan praktik. Evaluasi dilakukan terhadap tingkat pengetahuan dan keterampilan mitra dalam pembuatan double action hand sanitizer berbasis minyak sereh wangi sebagai antiseptik dan mosquito repellent sampai siap pakai dan keterampilan mitra 
dalam memasarkan produk baik secara offline maupun online. Kegiatan monitoring dan evaluasi (monev) terhadap implementasi double action hand sanitizer berbasis minyak sereh wangi dilakukan bersamaan kegiatan pendampingan.

\section{HASIL DAN PEMBAHASAN}

Kegiatan PPM di Panti Asuhan Yatim Piatu dan Dhuafa Khaira Ummah, Sriwulan, Sayung, Demak melalui penerapan teknologi tepat guna produksi hand sanitizer minyak sereh wangi yang berfungsi double action hand sanitizer sebagai antiseptik dan mosquito repellant alami dilakukan pada tanggal 8 dan 15 November 2020.

Berdasarkan analisis situasi dan permasalahan yang dihadapi mitra, prioritas persoalan yang akan diselesaikan adalah masalah keterbatasan pengetahuan dan keterampilan tentang produksi dan formulasi double action hand sanitizer berbasis minyak sereh wangi sebagai antiseptik dan mosquito repellent yang berpeluang untuk dijadikan potensi bisnis baru. Secara umum solusi permasalahan aspek teknologi formulasi double action hand sanitizer melalui tahapan yang ditunjukkan pada Gambar 1.

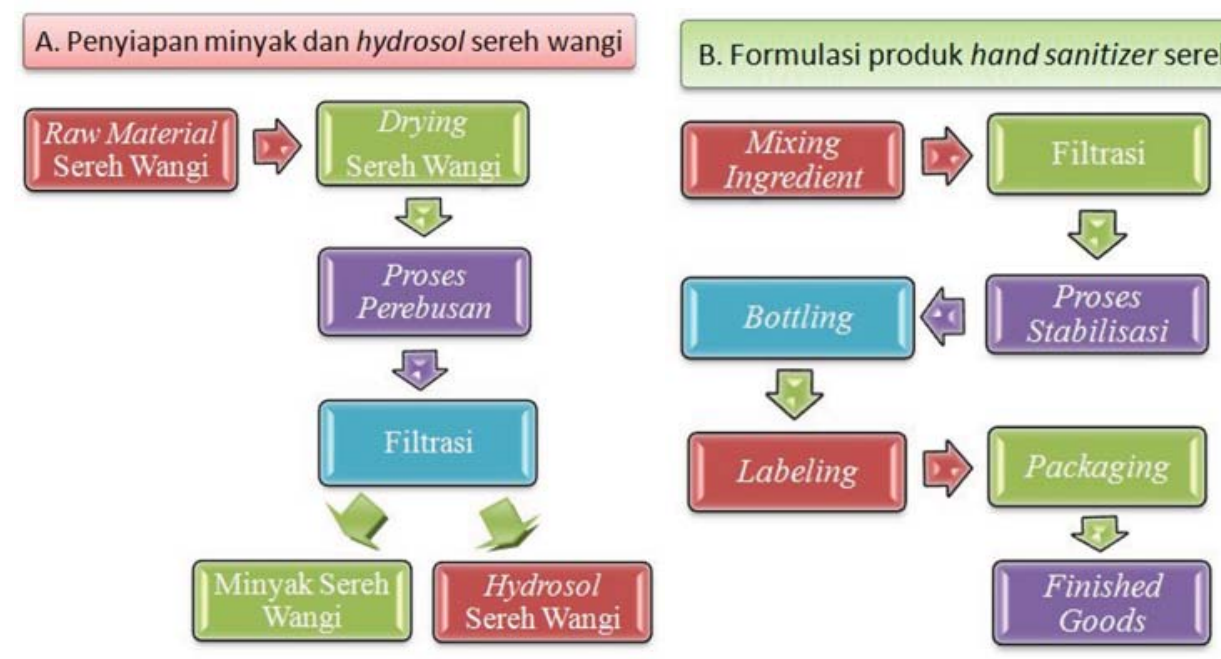

Gambar 1. Skema tahapan produksi double action hand sanitizer

berbasis minyak sereh wangi sebagai antiseptik dan mosquito repellent di Panti Asuhan Yatim Piatu dan Dhuafa Khaira Ummah, Sriwulan, Sayung, Demak

Pelaksanaan kegiatan PPM diawali dengan transfer pengetahuan tentang hand sanitizer, antiseptik, mosquito repellent, tanaman sereh wangi, dan cara mendapatkan minyak sereh dan hydrosol yang disampaikan melalui ceramah dan diskusi melalui handout seperti ditunjukkan pada Gambar 2.

Bahan dasar pembuatan hand sanitizer adalah alkohol yang pada kegiatan ini digunakan etanol dan isopropil alkohol (Herlina et al., 2020; Tambunan \& Sulaiman, 2018; Ningsih et al., 2017). Penggunaan isopropil alkohol berfungsi menggantikan etanol yang sejak pandemi Virus Corona, menjadi barang langka karena pembelian yang masif dari masyarakat. Sebenarnya penggunaan isopropil alkohol dapat menggantikan etanol seluruhnya, namun berdasarkan hasil formulasi didapatkan komposisi etanol yang optimal sebesar $20 \%$ dan isopropil alkohol sebesar $54 \%$. Dengan komposisi yang ditunjukkan pada Tabel 1, hand sanitizer yang dihasilkan berfungsi optimal sebagai antiseptik dan mosquito repellent dan selain itu masih adanya kandungan etanol dalam hand sanitizer sensasi dingin masih didapatkan, 
ABDIMAS: Jurnal Pengabdian Masyarakat Universitas Merdeka Malang

Volume 7, No 1, February 2022: 94-102

jika dibandingkan hanya menggunakan seluruhnya dengan isopropil alkohol. Sebelum dilakukan proses formulasi hand sanitizer berbasis minyak sereh. Terlebih dahulu, mitra diberi pengetahuan cara memproduksi minyak dan hydrosol sereh wangi dengan cara sederhana. Seperti yang ditunjukkan pada Gambar 1, untuk mendapatkan minyak dan hydrosol sereh wangi, material sereh wangi yang digunakan adalah bagian batang dari tanaman sereh wangi dikeringkan dengan cara diangin-anginkan dan tidak boleh terkena sinar matahari langsung. Setelah kering, dapat dilakukan proses perebusan dengan tempat tertutup. Setelah selesai, dilakukan proses filtrasi atau penyaringan dengan menggunakan kain monel atau kain yang digunakan untuk sablon. Air rebusan minyak sereh wangi atau disebut sebagai hydrosol sereh wangi akan turun melawati kain monel sedangkan minyak sereh wangi akan ditertinggal diatas kain monel.

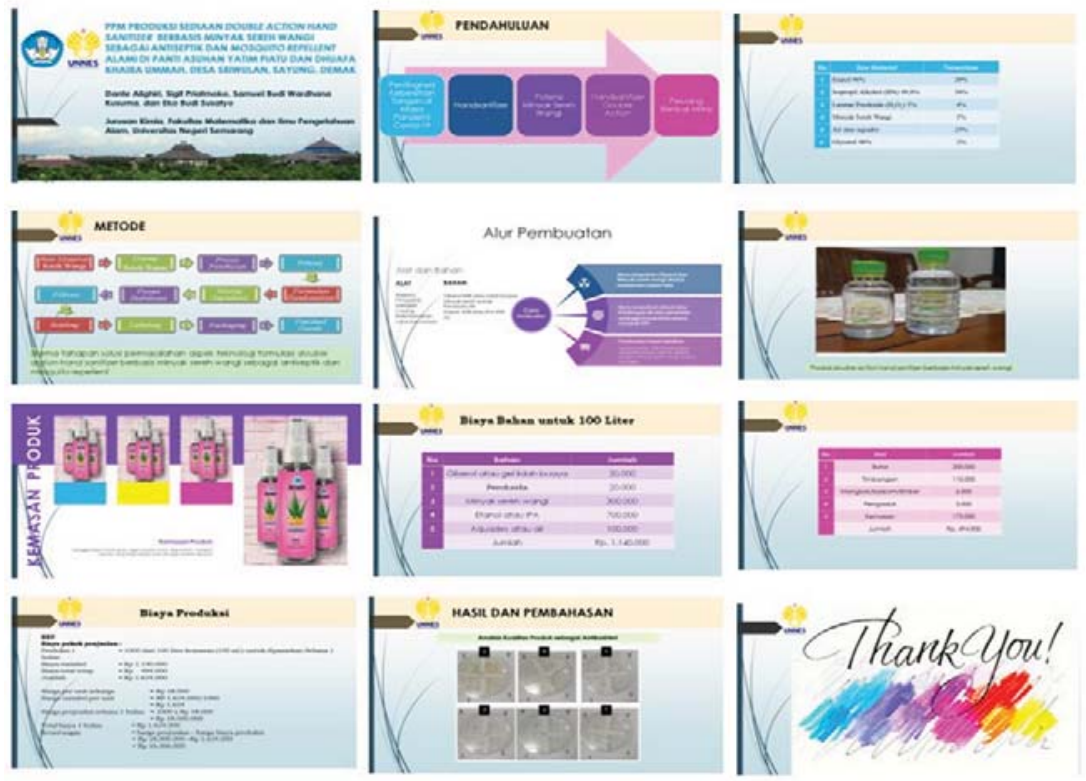

Gambar 2. Handout produksi double action hand sanitizer berbasis minyak sereh wangi sebagai antiseptik dan mosquito repellent di Panti Asuhan Yatim Piatu dan Dhuafa Khaira Ummah, Sriwulan, Sayung, Demak

Setelah didapatkan minyak dan hydrosol sereh wangi, tahapan selanjutnya adalah proses demonstrasi dan praktik produksi hand sanitizer berbasis minyak sereh wangi berdasarkan formulasi pada Tabel 1. Tahapan produksinya ditunjukkan pada Gambar 1, yaitu etanol, isopropil alkohol, hydrosol minyak sereh wangi dicampur terlebih dahulu sampai larutan menjadi homogen (Campuran A). Kemudian, minyak sereh wangi dan gliserol dicampurkan dalam wadah yang terpisah sampai homogen (Campuran B). Campuran B ditambahkan secara perlahan ke dalam campuran A dan diaduk sampai homogen agar dihasilkan produk hand sanitizer yang clear dan colorless.

Kegiatan PPM ditunjukkan pada Gambar 3 dan kegiatan praktik produksi hand sanitizer minyak sereh wangi di Panti Asuhan Khaira Ummah di Asrama Putri ditunjukkan pada Gambar 4 sedangkan di Asrama Putra ditunjukkan pada Gambar 5.

Hasil pelatihan dalam bentuk demonstrasi dan praktik langsung dihasilkan 10 liter hand sanitizer yang dibagi menjadi dua kemasan isi ulang masing-masing dengan kapasitas 210 dan $110 \mathrm{~mL}$ serta kemasan botol spray kapasitas 60 mL, contoh produk hasil kegiatan PPM ditunjukkan pada Gambar 6 . 

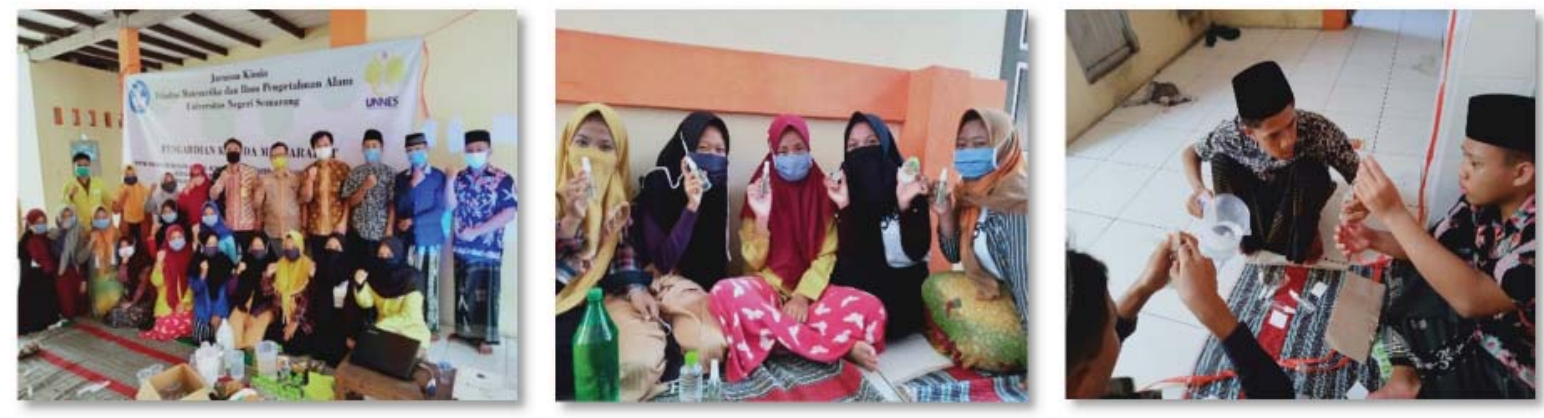

Gambar 3. Kegiatan PPM penerapan teknologi tepat guna produksi hand sanitizer minyak sereh wangi

Gambar 4. Kegiatan pelatihan praktik produksi hand sanitizer minyak sereh wangi

Gambar 5. Kegiatan pelatihan praktik produksi hand sanitizer minyak sereh wangi
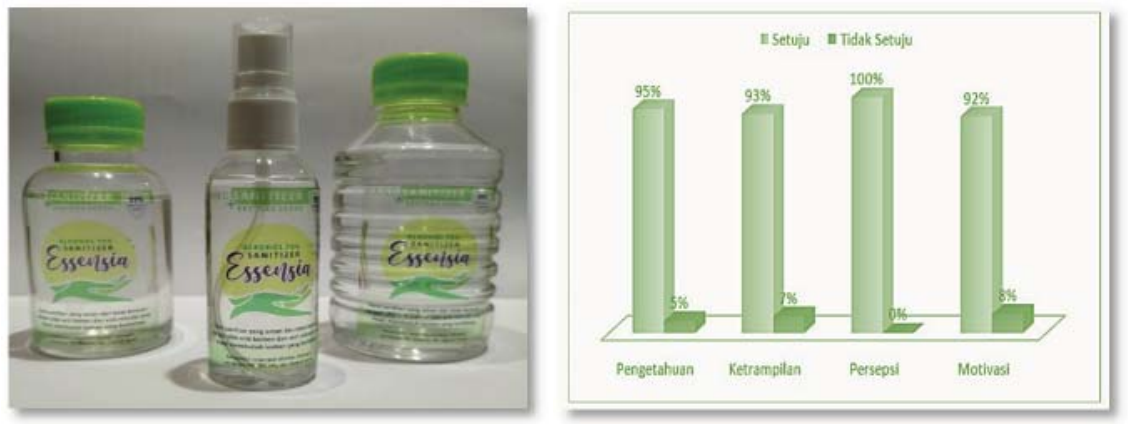

Gambar 6. Contoh produk hand sanitizer minyak sereh wangi kemasan botol isi ulang 210 dan $110 \mathrm{~mL}$ serta kemasan botol spray hasil kegiatan PPM

Gambar 7. Hasil angket pemahaman kegiatan PPM produksi hand sanitizer minyak sereh wangi

Hasil kegiatan ini selain diharapkan dapat mendukung pola hidup bersih dengan selalu menggunakan hand sanitizer setelah melakukan segala aktivitas terutama di lingkungan panti asuhan namun diharapkan juga dapat memberikan inspirasi ide kreatif anak-anak panti dalam membuka usaha baru yaitu pembuatan hand sanitizer yang khas. Hasil kegiatan PPM dirangkum pada Tabel 2, berdasarkan tabel tersebut terlihat bahwa kegiatan sudah dapat berjalan dengan baik dan semua terlaksana 100\% dan dengan tingkat keberhasilan program mencapai $100 \%$.

Berdasarkan Gambar 7, tingkat pemahaman peserta terhadap seluruh kegiatan PPM ini hampir seluruh peserta merasa paham.

Namun demikian, untuk tingkat motivasi terdapat $8 \%$ peserta yang masih merasa ragu tentang potensi bisnis produk-produk perbekalan kesehatan rumah tangga khususnya dalam pelatihan ini adalah potensi bisnis produk hand sanitizer berbasis minyak sereh. Hal ini, kemungkinan disebabkan peserta membutuhkan pelatihan khusus tentang kewirausahan dalam hal ini memasarkan produk hand sanitizer terutama pemasaran digital yang sedang tren di era sekarang.

Indikator keberhasilan program kegiatan PPM dilakukan dengan melakukan kegiatan evaluasi melalui kuesioner kepuasan dan pemahaman materi tentang pengetahuan dan keterampilan produksi hand sanitizer berbasis minyak sereh wangi. Evaluasi ini bertujuan untuk menguji tingkat ketercapaian 
ABDIMAS: Jurnal Pengabdian Masyarakat Universitas Merdeka Malang Volume 7, No 1, February 2022: 94-102

tujuan, sasaran, dan luaran kegiatan PPM. Hasil analisis evaluasi kuesioner ditunjukkan pada Gambar 8. Berdasarkan hal tersebut, dapat disimpulkan bahwa sebagian besar peserta kegiatan PPM ini yaitu sebesar 95,2\% telah memahami luaran kegiatan yang direncanakan dan menyatakan bahwa kegiatan ini sudah sesuai dengan harapan.

Tabel 2. Capaian hasil kegiatan PPM Panti Asuhan Yatim Piatu dan Dhuafa Khaira Ummah, Sriwulan, Sayung, Demak

\begin{tabular}{|c|c|c|}
\hline Jenis Kegiatan & Capaian (\%) & Keterangan \\
\hline \multicolumn{3}{|l|}{ Persiapan kegiatan PPM } \\
\hline $\begin{array}{l}\text { a. Koordinasi Tim PPM, mitra dan LP2M Universitas Negeri } \\
\text { Semarang yang mencakup administrasi dan perizinan }\end{array}$ & 100 & Sudah dilakukan dengan baik \\
\hline $\begin{array}{l}\text { b. Proses sosialisasi tentang PPM double action hand sani- } \\
\text { tizer berbasis minyak sereh wangi }\end{array}$ & 100 & $\begin{array}{l}\text { Sudah dilakukan dan dapat } \\
\text { diterima dengan baik }\end{array}$ \\
\hline \multicolumn{3}{|l|}{ Pelaksanaan kegiatan PPM } \\
\hline $\begin{array}{l}\text { a. Ceramah dan diskusi tentang pengetahuan double ac- } \\
\text { tion hand sanitizer berbasis minyak sereh wangi }\end{array}$ & 100 & $\begin{array}{l}\text { Sudah dilakukan dan dapat } \\
\text { diterima dengan baik }\end{array}$ \\
\hline $\begin{array}{l}\text { b. Demonstrasi dan praktik produksi hand sanitizer berba- } \\
\text { sis minyak sereh wangi }\end{array}$ & 100 & $\begin{array}{l}\text { Sudah dilakukan dan dapat } \\
\text { diterima dengan baik }\end{array}$ \\
\hline $\begin{array}{l}\text { c. Pendampingan praktik kegiatan produksi formulasi } \\
\text { double action hand sanitizer berbasis minyak sereh } \\
\text { wangi }\end{array}$ & 100 & $\begin{array}{l}\text { Sudah dilakukan dan dapat } \\
\text { diterima dengan baik }\end{array}$ \\
\hline $\begin{array}{l}\text { d. Melakukan analisis kualitas produk double action hand } \\
\text { sanitizer }\end{array}$ & 100 & Sudah dilakukan dengan baik \\
\hline \multicolumn{3}{|l|}{ Formulasi double action hand sanitizer } \\
\hline $\begin{array}{l}\text { Demonstrasi dan praktik formulasi double action hand sani- } \\
\text { tizer berbasis minyak sereh wangi }\end{array}$ & 100 & $\begin{array}{l}\text { Sudah dilakukan dan dapat } \\
\text { diterima dengan baik }\end{array}$ \\
\hline \multicolumn{3}{|l|}{ Monitoring evaluasi kegiatan PPM } \\
\hline $\begin{array}{l}\text { Evaluasi dilakukan melalui unjuk kerja pada semua aspek } \\
\text { produksi teknologi formulasi }\end{array}$ & 100 & $\begin{array}{l}\text { Sudah dilakukan dan dapat } \\
\text { diterapkan dengan baik }\end{array}$ \\
\hline
\end{tabular}

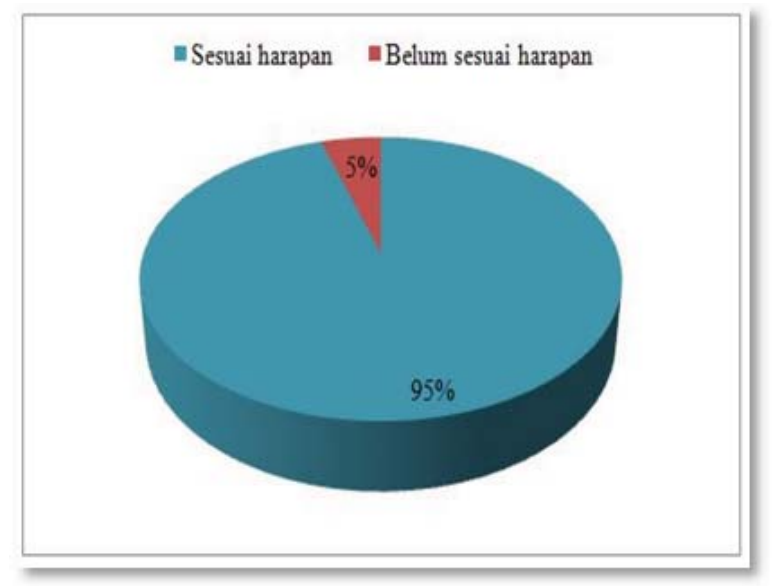

Gambar 8. Hasil angket evaluasi kegiatan PPM produksi hand sanitizer minyak sereh wangi di Asrama Putra Panti Asuhan Khaira Ummah Sriwulan, Sayung, Demak 


\section{SIMPULAN DAN SARAN}

Kegiatan PPM ini berhasil membekali anak-anak panti asuhan dengan pengetahuan dan keterampilan yang diharapkan dapat memberikan ide kreatif dalam berwirausaha melalui penerapan teknologi tepat guna produksi hand sanitizer minyak sereh wangi di Panti Asuhan Khaira Ummah Sriwulan, Sayung, Demak. Kegiatan ini juga mendukung visi Panti Asuhan Yatim Piatu dan Dhuafa Khaira Ummah, Sriwulan, Sayung, Demak dalam mewujudkan generasi yang khaira ummah.

Keberlanjutan dan keterlibatan kegiatan PPM dengan universitas seperti ini selalu diharapkan oleh Panti Asuhan Yatim Piatu dan Dhuafa Khaira Ummah, Sriwulan, Sayung, Demak untuk membantu mewujudkan visi panti asuhan dan mendukung kegiatan-kegiatan yang ada di panti asuhan yang terkendala baik pendanaan maupun pengetahuan.

\section{UCAPAN TERIMA KASIH}

Ucapan terima kasih kepada Fakultas Metematika dan Ilmu Pengetahuan Alam, Universitas Negeri Semarang yang telah mendanai kegiatan PPM ini melalui Daftar Isian Pelaksanaan Anggaran (DIPA), Universitas Negeri Semarang, Nomor: 4.28.5/UN37/PPK.4.4/2020, tanggal 28 bulan Mei tahun 2020.

\section{DAFTAR PUSTAKA}

Alfhili, M.A., \& Lee, M.H.(2019). Triclosan:An update on biochemical and molecularmechanisms. Oxidative Medicine and Cellular Longevity, 2019, 1-28. https://doi.org/10.1155/2019/1607304

Alighiri, D., Cahyono, E., Eden W. T., Kusuma, E. \& Supardi, K. I. (2018). Study on the improvement of essential oil quality and its repellent activity of Betel Leaves Oil (Piper betle L.) from Indonesia. Oriental Journal of Chemistry, 34(6), 2913-2926. https://doi.org/10.13005/ojc/340631

Alighiri, D., Eden, W. T., Supardi, K.I., Masturi \& A. Purwinarko, A. (2017). Potential development essential oil production of Central Java, Indonesia. Journal of Physics: Conference Series, 824(1), 012021. https://doi.org/10.1088/1742-6596/824/1/012021

Aziz, R. Wahyuni, E. S., Efiyanti, A. Y., \& Wargadinata, W. (2020). Membangun sikap optimis remaja yatim/piatu melalui pelatihan wirausaha di Dusun Sendang Biru Kabupaten Malang. E-Dimas: Jurnal Pengabdian kepada Masyarakat, 11(3), 260-266.

https://doi.org/10.26877/e-dimas.v11i3.3522

Choiriyah, N. A., Devi, I. M. R., Sanjaya, S. A., Dewi, I. C., \& Rahmah, L. (2021). Penyuluhan pencegahan penularan COVID-19 di lingkungan kantor dan pembuatan Lemongrass Coolant melalui Live Zoom. Abdimas: Jurnal Pengabdian Masyarakat Universitas Merdeka Malang, 6(1), 18-26. https://doi.org/10.26905/abdimas.v6i1.4865

Eden, W. T., Alighiri, D., Cahyono, E., Supardi, K.I. \& Wijayat, N. (2018). Fractionation of Java Citronella Oil and Citronellal Purification by batch vacuum fractional distillation. IOP Conference Series: Materials Science and Engineering, 349(1), 012067. https://doi.org/10.1088/1757-899x/349/1/012067

Eden, W. T., Alighiri, D., Supardi, K. I., \& Cahyono, E. (2020). The mosquito repellent activity of the active component of air freshener gel from Java Citronella Oil (Cymbopogon winterianus). Journal of Parasitology Research, 2020, 1-5. https://doi.org/10.1155/2020/9053741

Herlina, E., Widiastuti, D., \& Triadi, A. (2020). Potensi minyak atsiri Bunga Kenanga (Cananga odorata) sebagai antibakteria dalam sediaan hand sanitizer gel. Ekologia : Jurnal Ilmiah Ilmu Dasar dan Lingkungan Hidup, 20(2), 88-94. 10.33751/ekologia.v20i2.2171. 
ABDIMAS: Jurnal Pengabdian Masyarakat Universitas Merdeka Malang Volume 7, No 1, February 2022: 94-102

Ningsih, D. R., Zusfahair, Kartika, D., \& Fatoni, A. (2017). Formulation of handsanitizer with antibacterials substance from n-hexane extract of Soursop Leaves (Annona Muricata Linn). Malaysian Journal of Fundamental and Applied Sciences, 13(1), 1-5. https://doi.org/10.11113/mjfas.v13n1.527

Sastrohamidjojo, H. (2004). Kimia minyak atsiri. Yogyakarta: Gajah Mada University Press.

Setiawan, K. \& Pasau, P. (2017). IbM pemberdayaan anak panti asuhan. E-Dimas: Jurnal Pengabdian kepada Masyarakat, 8(2), 227-235. https://doi.org/10.26877/e-dimas.v8i2.1453

Standar Nasional Indonesia. (1995). Standar nasional Indonesia minyak sereh wangi. Jakarta: Badan Standarisasi Nasional.

Syafi'i I., Cahyono E., Mahatmanti, F. W., \& Alighiri, D. (2020). Sintesis ñ-mentana-3, 8-diol dan aplikasinya sebagai gel air freshener penolak Nyamuk Aedes aegypti. Indonesian Journal of Chemical Science, 9(3), 205-213.

Tambunan, S. \& Sulaiman, T. N. S. (2018). Formulasi gel minyak atsiri sereh dengan basis HPMC dan Karbopol. Majalah Farmaseutik, 14(2), 87-95.

World Health Organization. (2020). Guide to local production: WHO-recommended handrub formulations. New York: WHO. https://doi.org/10.17504/protocols.io.bdqei5te 